\title{
The nexus between maize importation, local production and local prices: Empirical analysis from Nigeria
}

(Research Article)

Misır İthalatı, Yerli Üretim ve Yerel Fiyatlar Arasındaki Bağlantı: Nijerya'da Gözlemsel Bir Analiz

Doi: 10.29023/alanyaakademik.481553

\section{Kehinde Paul ADEOSUN}

Ph.D candidate, Department of Agricultural Economics, University of Nigeria, Nsukka paul.adeosun@unn.edu.ng

Orcid No: 0000-0002-8061-5851

\section{Eberechukwu Johnpaul IHEMEZIE}

Ph.D candidate, Department of Agricultural Economics, University of Nigeria, Nsukka eberechukwu.ihemezie@unn.edu.ng

Orcid No: 0000-0002-4714-295X

\section{Chukwuma Otum UME}

Ph.D candidate, Department of Agricultural Economics, University of Nigeria, Nsukka chukwuma.ume@unn.edu.ng

Orcid No: 0000-0003-2033-0560

\section{Livinus Uchenna EGU}

Ph.D candidate, Department of Agricultural Economics, University of Nigeria, Nsukka kennypaul062005@yahoo.com Orcid No: 0000-0001-8348-8475

How to cite this article: Adeosun, P.K, Ihemezie, J.E., Ume, O.C., \& Egu, U.L. (2019). The nexus between maize importation, local production and local prices: Empirical analysis from Nigeria. Alanya Academic Review, 3(2), 201-213.

\begin{tabular}{|c|c|}
\hline & ABSTRACT \\
\hline eywords & $\begin{array}{l}\text { The study examined the relationship between maize importation, local prices } \\
\text { and local production. Secondary data from } 1970 \text { to } 2016 \text { were employed. } \\
\text { Unit root, co-integration and Ordinary Least Square (OLS) assumption tests }\end{array}$ \\
\hline $\begin{array}{l}\text { Agricultural } \\
\text { development, } \\
\text { Import substitution, } \\
\text { Generalized Least } \\
\text { Square }\end{array}$ & $\begin{array}{l}\text { were checked. Least Square estimation model, Pearson Coefficient and } \\
\text { Generalized Least Model }(G L M) \text { were employed. The results show that } \\
\text { strong linear relationship }(-0.466) \text { exist between local maize production and } \\
\text { maize importation, though in opposite direction. The results from GLM } \\
\text { shows that quantities of maize imported }(-0.0324) \text {, sorghum production }(- \\
0.967) \text { and population growth }(-0.779) \text { are statistically significant but }\end{array}$ \\
\hline $\begin{array}{l}\text { Received: } 12.11 .2018 \\
\text { Accepted: } 21.01 .2019\end{array}$ & $\begin{array}{l}\text { negatively influences local maize production. Local price of maize (0.471) } \\
\text { on the other hand is positive and significantly influences local maize } \\
\text { production. There should be effective government policy to reduce maize } \\
\text { importation. }\end{array}$ \\
\hline
\end{tabular}




\section{INTRODUCTION}

One of the major problems facing Nigeria's agriculture is inconsistency in the government policies particularly in the areas of importation of agricultural produce and this has serious (negative) influence on local production and a spillover effect on rural farmer's welfare that makes up the bulk of Nigeria agricultural producers. These inconsistencies over the years coupled with lack of political will to stabilize the agricultural sector of the economy have made the Nigerian agricultural production to experience low yield and reduction in local production to its lowest ebb. Hence, these posed negative effect on Nigerian farmer's welfare (Onuk et al. 2010). One of the major disturbing phenomena in Nigeria today is the shortage of food grains with the attendant result of soaring prices and rising importation of these commodities. This shortage can be attributed to a number of factors among which are the increase in population which is not matched by the rate of growth in the food production and poor storage system (Akanni \& Okeowo, 2011).

Conversely, Nigerian government responsibility is to provide an adequate and well stable food supply to meet the requirement of a growing population seems to be on the edge of being defeated. These have forced the nation to resort to importation as the only way to dissipate food shortage in the country. According to Alabi \& Alabi (2009), agricultural sector was the then main stay of the Nigerian economy before and immediately after independent, until the oil boom of 1970s. In the period before 1970s, agriculture provides the needed food for the population and served as the major foreign exchange earner for the nation (International Institute of Tropical Agriculture, IITA, 2017). The significant of maize production to modern society is first and foremost reflected in the importance of the crop in the diet of man and animals throughout the world (Onwueme \& Sinha, 1991).

According to report released in fourth quarter of 2017 by the National Bureau of Statistics (NBS), Nigeria imported maize from foreign countries that worth about N146.8billion annually (NBS, 2017). It is obvious that such policy on importation cannot bring permanent solution to food security rather it fuels inflation, discourages local production, created poverty among households. Therefore, Nigeria cannot continue to depend on importation to feed her growing population, thus, there is need to encourage local production by providing good market in terms of prices.

Alabi and Alabi (2009) noted that during the period of oil boom of 70s and 80s, attention was shifted to petroleum sector and agricultural sector was totally neglected and huge sum of money from oil production sales was used for importation of some of agricultural products and food grains, maize inclusive. This huge importation of grains rendered the locally produced maize incapable of competing with foreign ones because production cost is usually high while modern technique in production is not available. As a result, there was a demand supply gap in maize production in Nigeria, which still exists till date. In order to address the demand-supply gap, government has at various times come up with policies. However, these policies and programmes have not been consistent. In order to encourage local production and boost the morale of maize farmers to continue production, there is need to examine those factors that discourage local production among which is differential in the pricing of imported and locally produced maize.

Contributing to the solution of the above problem, this study aims to determine the relationship between maize importation, local prices and local production in Nigeria. Specifically, the study aims to; i) determine the effect of maize importation on local maize production in Nigeria, and ii) examine the relationship between maize importation, local 
prices and local maize production. This is important because in the recent time, Nigeria has witnessed unprecedented mass importation of maize and other agricultural products into the country which can be produced locally at a lower cost. The relationship between maize importation and local production needs to be examined for appropriate policy formulation on cereal crop import restriction in Nigeria particularly maize importation. The study therefore will be of immense benefit to policy makers, government official in the Ministry of Agriculture, researchers and other stakeholders in the agricultural sector of the economy as it will give direction on how to enhance agricultural policy in Nigeria.

\section{THEORETICAL AND CONCEPTUAL FRAME WORK}

\subsection{Import Substitution Industrialization}

Import Substitution Industrialization (ISI) is a development theory of trade and economic policy which advocates for replacement of foreign importation with domestic production (Baer, 1972; Mendes et al. 2014). This theory which is often linked with the dependency theory proposes that countries, especially developing countries should attempt to reduce its foreign dependency through the local production of imported products. It is thus a form of an inward-looking economic policy that advocates for increased productivity and economic gains within a country. Since the development of the theory in the 20th century, several countries in the Global South have applied its policies in development and creation of selfsufficient internal markets. The ISI theory functions through centrally controlled and state led economic policies of nationalization, subsidization, increased taxation, high tariff on importation, and protectionist trade policies (Chang, 2002). The theory advocates for stateinduced development by government spending through primary sectors such as agriculture.

It has been argued that almost all industrialized nations at one point in their development trajectory applied the ISI model. Many economists considered the ISI approach as a remedy to mass poverty, and unemployment (Adewale, 2017; Guimarães, 2004). Baer (1972) and Irwin (2002) contend that all developed economies that emerged after the United Kingdom went through the ISI development stages, where large part of national investments were directed to replace importation and grow the local economy. Furthermore, Chang (2002) also argue based on economic history that all developed nations applied the interventionist economic policies to promote local production and local producers until they had attained a development level where they are able to compete in the global market. It was after this ISI stage that those developed economies opened up to free market discourses, which was actually meant to serve two purposes: create international market for their local products, and to prevent the emerging economies from adopting the ISI strategies that led to their development (Chang, 2002). Thus, if the developing economies must grow beyond foreign dependence, it has to map out strategies such as the ISI to develop its local economy (Panagariya, 2002).

The same approach can be applied in the development of the agricultural sector in Nigeria. By placing high tariffs on the importation of agricultural products that can be produced in Nigeria such as Maize, the country can grow its agricultural industry. With this, the primary agricultural industry would accumulate and produce resources such as capital, raw materials and labour which would be transferred to the industrial. With time, as the country gains more accumulation of capital and increase total factor productivity (TFP), the country would, in principle, be able to trade internationally and compete in the world market.

However, irrespective of the recorded successes of the ISI model, it has been criticized for its inability to sustain economic growth in the long run. Advocates of neoliberal economics have 
argued that while import substitution policies have the potential to create employment and improve the local production in the short run, through domestic substitution of foreign producers, it can slow output and growth in the long run (Pouget-Abadie, 2016; Adewale, 2012). This according to them is because the ISI model tends to shield the local economy from the benefits of globalization and technological transfer that comes through foreign importation. Their argument is based on the theory of comparative advantage which proposes that countries will gain more from international trade. Colistete (2010) noted that the protectionism approach of the ISI model might lead to dynamic inefficiency of domestic producers who will have little or no incentive from foreign competitors to reduce production costs and/or improve products. Thus these disadvantages of ISI model (lack of international competition and reduced innovation and efficiency) may lead to high prices of locally produced goods.

Nevertheless, critics of neoliberal economics have also argued that eliminating tariff in countries with immature tax system a common feature of many developing economies, will reduce government revenue needed to service public debts, build public infrastructure, and develop local production (Hunt, 2014; Nkwocha, 2012; Dev, 2003). Again, it is worthy to note that import substitution does not mean import elimination. No country can do without importation. As a country develops, importation of new materials becomes necessary for its local product (Guimarães, 2004). In the case of agricultural development, farm inputs and technologies such as improved seeds, machineries, etc can be imported to support and develop local production. A situation where final agricultural products such as maize are imported stifles local production. In the modern production theory approach to import demand, imported goods are considered as intermediate products rather than as final goods. This is because of the nature of international trade where imported goods are either used in other production processes or go through a number of domestic channels before reaching the final consumer. It is thus more appropriate to allow only the importation of those goods that will be used to enhance local production ( $\mathrm{Zhu}, 2006$ ). In economic growth, although agricultural products such as maize are not usually considered as final good, they are however considered final agricultural products, and as such their importation especially at cheaper rates reduces the incentive for local production. What the government should do is to invest in those technologies that will reduce local cost of production so that locally produced maize can favourably compete with the price in the global market (Shuman, 2006). Restriction in the importation of maize and allowing the importation of only agricultural input goods will contribute a great deal to agricultural development in Nigeria. In line with the ISI theory, a conceptual framework is developed to analyse the nexus between maize importation, local production, and local prices in Nigeria.

Analyzing the nexus between maize importation, local production, and local prices is to examine the factors militating against efficient contribution of maize production to agricultural development. The framework shows how the negative impact of maize importation on local production can be cushioned by the application of ISI strategies together with investments in technologies that will reduce the production cost of local maize. While the ISI strategies which this paper advocates is expected to improve self-sufficiency in local maize production, investment in production cost-reduction technologies will make locally produced maize to be more competitive by reducing its market price. The overall effect will reduce over reliance on maize importation; stimulate local production, which will in turn increase the income of local maize farmers, thus motivating them to increase production. Overall improvement in local maize production will contribute immensely to agricultural development in Nigeria. 


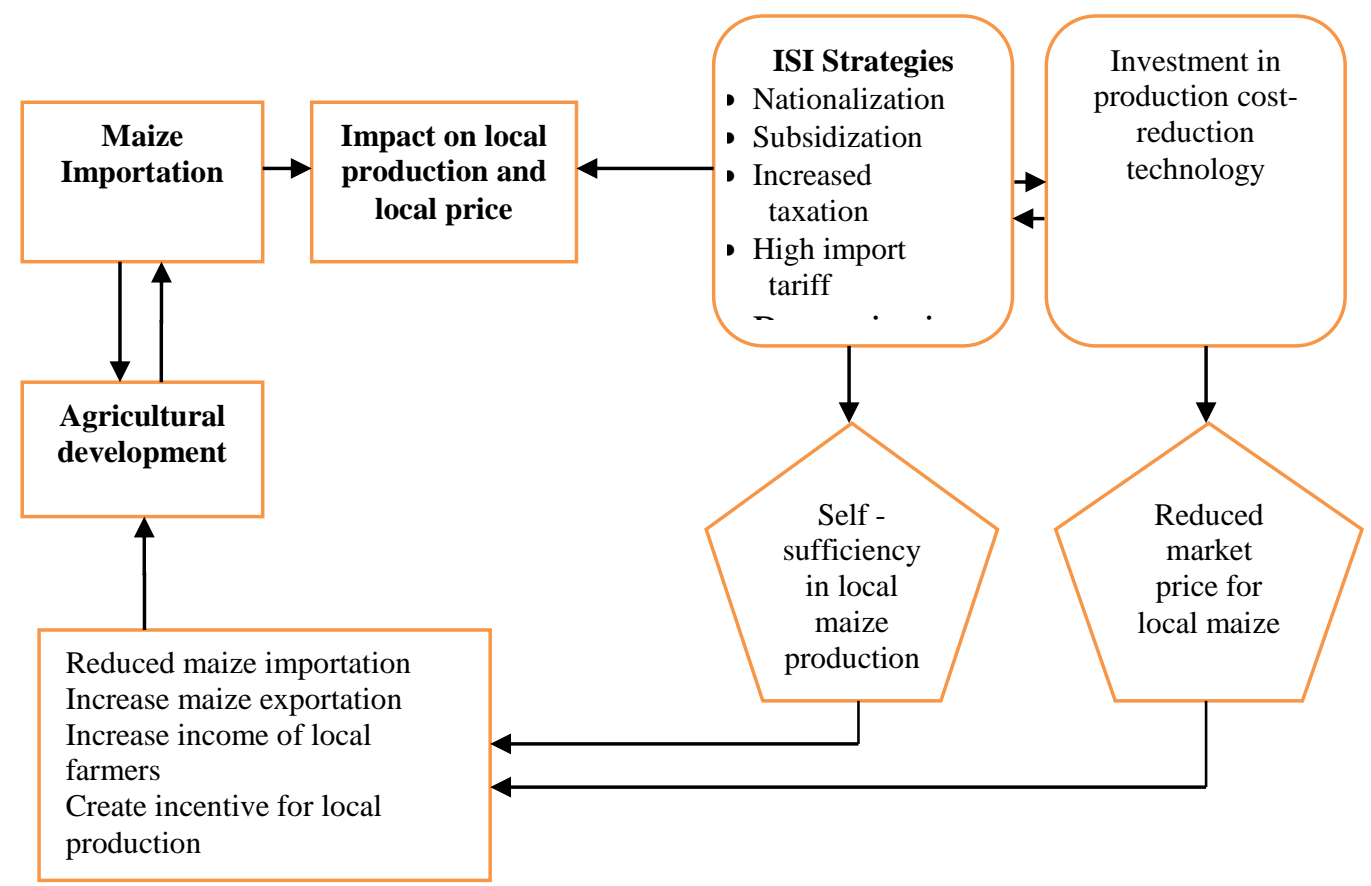

Figure 1. Conceptual framework

\section{MATERIALS AND METHODS}

\subsection{Study Area}

Nigeria is the study area. The country has a total geographical area of 923,768 square kilometer and a population of about 190 million people (National Population Commission (NPC), 2010). Nigeria lies within the tropics along the Gulf of Guinea on the western coast of Africa. Nigeria is located between latitudes 40 to 140 North 2040 and between longitudes 202' and 14o41 East (CIA Fact Book, 2012). To the North, the country is bounded by Niger Republic $(1497 \mathrm{~km})$ and Chad $(853 \mathrm{~km})$ to the West by Benin Republic $(773 \mathrm{~km})$ to the East by the Cameroon Republic $(1,690 \mathrm{~km})$ and to South by the Atlantic Ocean (NBS, 2017). Nigeria has a highly diversified agro-ecological climatic condition and hence, agriculture constitutes one of the most important sectors of the Nigeria economy. The agricultural sector is particularly important in terms of its employment generation and its contribution to its domestic product (GDP) and export earnings. Administratively, Nigeria has 36 states with six geo-political zones and federal capital territory Abuja. The six geo-political zones are southeast, south-south, south-west, North-east, North central and North-west zones.

\subsection{Data Source}

Data used for the study were sourced from the National Bureau of Statistics (NBS) and Food and Agricultural Organization of the United Nations (FAO). The study used time series data from (1970-2016). Data sourced from FAO were quantities of maize imported, quantities of maize produced locally, maize local prices, quantities of sorghum, whilst population growth rate was sourced from NBS. 
Table 1. The descriptive statistics of the parameters employed in the model

\begin{tabular}{lcccc}
\hline Variables & Minimum & Maximum & Mean & Std. Deviation \\
\hline LMPROD & 488000 & 10562050 & 4601556.72 & 3048758.872 \\
QMI (tons) & 0 & 347282 & 38254.45 & 76965.430 \\
QME (tons) & 0 & 20273 & 2173.85 & 4367.321 \\
QS (tons) & 2298000 & 10000000 & 5571595.74 & 2154586.046 \\
PGR (\%) & 2 & 3 & 2.83 & 0.380 \\
LMP (naira per ton) & 68 & 95760 & 22991.04 & 28695.268
\end{tabular}

Source: data analysis, 2018

\subsection{Econometric procedure}

\subsubsection{Pearson correlation coefficient}

Ayinde et al., 2015) such as maize importation, local prices of maize and local maize production. Given the value of each parameters at time $t, X_{t}$ and $Y_{t}$, the degree of linear association between the parameters were measured by the sign and magnitude of the correlation, $r$. the model is stated below.

$\mathrm{r}=\frac{\sum_{i=1}^{n}((X i-\dot{X})(Y t-\bar{Y}))}{\sqrt{\sum_{i=1}^{n}(X i-\hat{X})^{\wedge} 2 \sum_{i=1}^{n}(Y i-\bar{Y})^{\wedge} 2}}(1)$

Where:

$r=$ Pearson correlation coefficient,

$\mathrm{X}_{\mathrm{i}}$ and $\mathrm{X}_{\mathrm{i}}=$ parameters at time $\mathrm{t}$

$\bar{Y}$ and $\dot{X}=$ mean of the parameters

\subsubsection{Generalized Linear Square Model (GLS)}

GLS is used over OLS in order to correct for heteroscedasticity when uncorrelated variance matrix has been ascertained. Then we used GLS regression model to find the effect of explanatory variables on the dependent variable. GLS correct for heteroscedasticity to make the variance constant (Kuan, 2004; Cameron and Travedi, 2008). The model is specified below.

$\mathrm{Y}=\mathrm{X} \mid \beta+\varepsilon \quad \mathrm{E}[\varepsilon]=0$

$\operatorname{Var}[\varepsilon]=\sigma^{2} \mathrm{~V}$

$\mathrm{E}\left(\mu \mu^{\prime}\right)=\sigma^{2} \Omega=\varepsilon$

$\Omega^{-1}=\mathrm{P}^{\prime} \mathrm{P}$

$P$ is a "n $x$ n" matrix

Pre-multiply $\mathrm{P}$ on a regression model

In this model, the variance of $\tilde{u}$ is

$\mathrm{E}\left(\tilde{u} \tilde{u}^{\prime}\right)=\mathrm{E} \mathrm{P}\left(\mu \mu^{\prime}\right) \mathrm{P}^{\prime}=\mathrm{P} \sigma^{2} \Omega \mathrm{P}^{\prime}=\sigma^{2} \mathrm{P} \Omega \mathrm{P}^{\prime}=\sigma^{2} 1$

Note that $P \Omega P^{\prime}=1$, because it is define as

$\mathrm{P} \Omega \mathrm{P}^{\prime}=\mathrm{A}$, then $\mathrm{P}^{\prime} \mathrm{P} \Omega \mathrm{P}^{\prime}=\mathrm{P}^{\prime} \mathrm{A}$

By the definition of $P \Omega^{-1} \Omega \mathrm{P}^{\prime}=\mathrm{P}^{\prime} \mathrm{A}$, thus $\mathrm{P}^{\prime}=\mathrm{P}^{\prime} \mathrm{A}$. Therefore, A must be 1

Because $\mathrm{E}\left(\tilde{u}_{\tilde{u}}^{\prime}\right)=\sigma^{2} 1$, the model satisfies the assumption of homoscedasticity. Then, we can estimate the model by the conventional OLS estimation.

Hence; $\beta=(\dot{X} \dot{X})^{-1} \dot{X} \tilde{y}$ 


$$
=\left(X^{\prime} P^{\prime} P X\right)^{-1} X^{\prime} P^{\prime} P y
$$

$\beta_{\mathrm{GLS}}=\left(\mathrm{X}^{\prime} \Omega^{-1} \mathrm{X}\right)^{-1} \mathrm{X}^{\prime} \Omega^{-1} \mathrm{y}$

$\operatorname{lnLMPROD}=\alpha_{o}+\beta_{1} \ln \mathrm{QMI}+\beta_{3} \ln \mathrm{PGR}+\beta_{6} \operatorname{lnLMP}+\beta_{6} \ln \mathrm{QS}+\beta_{7} \ln \mathrm{QME}+\mathrm{e}$

$\alpha_{\mathrm{o}}=$ Intercept, $\beta=$ coefficient

Where: LMPROD is Local maize production per year (tons), QMI is Quantity of Maize imported (tons), QME is Quantity of maize exported, PGR is Population growth rate (\%),LMP is Local maize prices (naira), QS is Quantity of other substitute (sorghum) (tons), e is error term. Based on the relationship stated in equation (7), the aprori expectation is that $\mathrm{QMI}<0, \mathrm{QME}>0, \mathrm{PGR}>0, \mathrm{LMP}>0, \mathrm{QS}<0$ since increase population growth rate, and local price of maize will stimulate domestic maize production. While increase in maize importation and substitutes will discourage local maize production. All the variables (series) in the model are naturally logged to enable easy interpretation of results.

In order to ascertain the statistical properties of the time series data before incorporating to regression model, test were done to ascertain whether the mean value do vary with the sampling period to ensure long term relationship between and among variables and to prevent spurious regression. Based on this, unit root and stationarity test was done to validate the series before inclusion in the regression model denoted as $\mathrm{I}(0)$ or $\mathrm{I}(1)$. (Ayinde et al., 2015).Also, all assumptions of OLS were verified. Augmented Dickey-Fuller (ADF) and Johansen co-integration test were employed to verify the non-presence of unit root and stationarity respectively (Acosta, 2012). The model for ADF used in this study is shown below:

$\mathrm{Y}_{\mathrm{t}}=$

$\alpha \mathrm{X}_{\mathrm{t}}+$

$e_{t}$

(8)

Where; $\mathrm{Y}_{\mathrm{t}}$ is the dependent series, $\mathrm{X}_{\mathrm{t}}$ is the endogenous series and $\mathrm{e}_{\mathrm{t}}$ is the residual error.

\section{RESULTS AND DISCUSSION}

Maize is not only an important cereal crop produced in Nigeria on the basis of output but also on the basis of the number of farmers that produced it as well as its economic value (Olaniyi and Adewale, 2012). The results of the descriptive statistics of the key parameters employed in the study are shown in Table 1. These parameters were employed both in the correlation and regression model to ascertain their relationships and effects. Table 1 shows the average quantities of maize produced locally from the period of 1970 to 2016 to be $4,601,556.72$ tons, while the average quantities of maize imported from other countries is $38,254.45$ tons. The average quantity of maize exported to other countries for the same period is $2,173.85$ tons. While the average quantity of sorghum produced locally was 5,571,595.74 tons. The average local price of maize per tons for the period of 1970 to 2016 was $\$ 22,991.04$ per ton.

\subsection{Unit root test}

The results of the unit root test using Augmented Dickey Fuller (ADF) test to determine their stationarity with constant and time trend show that none of the variables were stationary at level but all were stationary at first difference as summarized in Table 2 . These show that there is no unit root in the series, hence all variables are integrated at order one I(1).

Table 2. Unit root test for stationarity using ADF

\begin{tabular}{llllll}
\hline Variables & $\begin{array}{l}\text { At levels } \\
\text { t-statistic }\end{array}$ & $\begin{array}{l}\text { Stationarity } \\
\text { decision }\end{array}$ & $\begin{array}{l}\text { 1st difference } \\
\text { t-statistic }\end{array}$ & $\begin{array}{l}\text { Stationarity } \\
\text { decision }\end{array}$ & Comment \\
\hline LMPROD & -1.8882 & Non stationary & $-6.0900^{* *}$ & Stationary & $\mathrm{I}(>1)$ \\
QMI & -2.6418 & Non stationary & $-8.71868^{* *}$ & Stationary & $\mathrm{I}(>1)$ \\
QME & -2.9561 & Non stationary & $-8.7186^{* *}$ & Stationary & $\mathrm{I}(>1)$ \\
QS & -2.9378 & Non stationary & $-9.6516^{* *}$ & Stationary & $\mathrm{I}(>1)$
\end{tabular}




\begin{tabular}{llllll} 
LMP & -2.9190 & Non stationary & $-7.5373 * *$ & Stationary & $\mathrm{I}(>1)$ \\
PGR & -2.0288 & Non stationary & $-3.76650^{* *}$ & Stationary & $\mathrm{I}(>1)$ \\
\hline
\end{tabular}

Source: data analysis, 2018

** denotes $5 \%$ probability level

\subsection{Co-integration test}

The results of the co-integration show that variables are co-integrated among themselves and its rank, depicting long run relationship among them.

Table 3. Determination of the co-integrating rank (Johansen Co-integration test)

\begin{tabular}{ccccc}
\hline $\begin{array}{c}\text { Hypothesized No. } \\
\text { of Co-integration }\end{array}$ & $\begin{array}{c}\text { Trace Eigenvalue } \\
\text { Test }\end{array}$ & \multicolumn{3}{c}{$\begin{array}{c}\text { Maximum } \\
\text { Eigenvalue Test }\end{array}$} \\
\hline & Trace statistic & $\begin{array}{c}\text { Critical value at } \\
\mathbf{5 \%}\end{array}$ & Max statistic & $\begin{array}{c}\text { Critical value at } \\
\mathbf{5 \%}\end{array}$ \\
\hline None & $185.1956^{*}$ & 94.15 & $85.7497^{*}$ & 39.37 \\
At most 1 & $99.4459^{*}$ & 68.52 & $52.1479 *$ & 33.46 \\
At most 2 & $47.2980^{*}$ & 47.21 & 26.9716 & 27.07 \\
At most 3 & 20.3264 & 29.68 & 13.0579 & 20.97 \\
At most 4 & 7.2684 & 15.41 & 5.5347 & 14.07 \\
At most 5 & 1.7338 & 3.76 & 1.7338 & 3.76 \\
\hline
\end{tabular}

Source: data analysis, 2018

\subsection{Linear Relationship of key parameters}

The correlation among the local maize production, maize importation, maize exportation and local maize prices were estimated to determine the level of the linear relationship. The Pearson correlation coefficient among the series depicts the direction of linear relationship. High correlation among some key parameters suggests an identifiable pattern of change among the parameters. The results on Table 4 show that local maize production is negatively associates with quantities of maize imported, the is in accordance with our apriori expectation that local production and importation are inversely related, such that when one increases, the other reduces. This is in line with the report of the World Food Conference which indicated that one of the means of boasting local production is by reducing food importation. Studies such as Uma, (2007) and Garnett \& Godfray, (2012) have also empirically analyzed the relationship between food import and local production and came up evidences of negative relationships.

The remaining variables were positively associated with local production. While quantities of maize imported is negatively associate with sorghum production may be because sorghum is substitute to maize, thus if sorghum production increase, maize importation will reduce. Madibela and Lekgari (2002) reported that when there was a decline in sorghum production in Botswana, it leads to increase in maize and wheat importation in the country. Maize importation will also force down the price of local maize therefore, the negatively correlation as it supports our apriori expectation. Quantity of maize exported is positively associates with sorghum production; this is against our apriori expectation. The reason may be that if there is increase in the production of both as substitutes, then, the exportation of the other will increase vice versa. The Pearson correlation coefficients of key parameters are statistically significant at $1 \%$ and $5 \%$ probability level. Hence, all the relationships among parameters are statistically significant except the correlation between LMPROD-PGR, QMI-QME, QMIPGR, QME-PGR, and QS-PGR. 
Table 4. Results of Pearson Correlation coefficient of key parameters in the study (1970-2016)

\begin{tabular}{|c|c|c|c|c|c|c|}
\hline Parameters & LMPROD & QMI & QME & QS & PGR & LMP \\
\hline LMPROD & & $-0.466 * * *$ & $0.537 * * *$ & $0.684 * * *$ & 0.121 & $0.894 * * *$ \\
\hline QMI & & & 0.189 & $-0.307 * *$ & 0.226 & $-0.350 * *$ \\
\hline QME & & & & $0.703 * * *$ & 0.089 & $0.695 * * *$ \\
\hline QS & & & & & -0.029 & $0.845^{* * *}$ \\
\hline PGR & & & & & & 0.205 \\
\hline LMP & & & & & & \\
\hline
\end{tabular}

Source: data analysis, 2018

** denotes $5 \%$ probability level

$* * *$ denotes $1 \%$ probability level

\subsection{Test for OLS assumptions}

The assumption of OLS was first verified to know whether it will be sufficient to use OLS model. All other assumptions were passed except for heteroscedasticity problem. For multicollinearity, the Tolerance (TOL) for all the variables was greater than 0.1 , while the Variance Inflation Factors (VIF) was less than 10 as it is summarized in Table 5. Also the normality test using Jarque-Bera, skewness and kurtosis was significant. While DurbinWatson score was 0.9644 which is greater than R2 of 0.88 shows that there is no autocorrelation. However, the null hypothesis for heteroscedasticity that there is equal variance was rejected because the Breusch-Pagan/Cook-Weisberg test was significant at 5\% probability level. This is summarized in Table 6. This necessitates for changing our model to GLS to avoid spurious regression. However, both the results of OLS and GLS were reported in the study. There is no significant difference between the two results but we decided to interpret the result of GLS because of the presence of heteroscedasticity which shows that GLS result will be more reliable.

Considering the parameters fitted in the regression model to measure the macroeconomic determinants of maize local production in Table 6. The result shows the Akaike information criterion (AIC) which measures the goodness of fit of the model. Smaller value of AIC indicates a better fit of a model and can also be used to compare models. The AIC is 0.9364 (Table 6) which shows an excellent fit of the model. From the parameters fitted into regression, four were statistically significant. Quantity of maize imported has negative relationship with local maize production and statistically significant at 5\% probability level. This is in accordance with our apriori expectation. This shows that if maize importation increases, it discourages local maize production as many farmers may feel reluctant to grow maize because of poor market due to flooding of market with foreign maize which will also pull down local prices. In addition, if the local maize production increases by 1 ton, it leads to reduction of maize importation by 3.24 tons. Nienke et al. (2011) reported that depending more on imports for food consumption is not only wasteful but detrimental to overall growth and future of the agricultural sector. Likewise, food commodities that a nation has comparative advantage for their production are being imported.

Akande (2001) opined that food importation itself is an obstacle to sustainable agricultural development and food security. Also, Sorghum production which at times serve as substitute to maize has negative relationship with maize production and statistically significant at $1 \%$ 
probability level. It agrees with our apriori expectation that the production of the two crops will be in opposite direction since they are substitutes. It explains that 1 ton increases in maize production may leads to 96.7 tons reduction in sorghum production. Also, population growth negatively influence maize production and statistically significant at $5 \%$ probability level as against our apriori expectation. Oladimeji (2017) produced similar results. Although, the population is increasing, it does not literarily translate to increase in maize production. This may be because, maize is not the number one major cereal crops consumed in Nigeria and may not be consumed by households on a regular basis unlike rice.

On the other hand, price of produce is one of the key determinants of production. In Table 6, the price of local maize positively influences maize production and statistically significant at $1 \%$ probability level. This supports our apriori expectation that increases in price will lead to increases production. Hence, one unit increases in price of maize will lead to increases of 47.1 tons of maize. Fluctuation in prices seriously affects cereal productivity in Nigeria (Ismila et al., 2010; Fakorede, 2001). Ayeni (2011) found out that low price for local maize discourages farmers from production.

Table 5. Results of Collinearity test

\begin{tabular}{lccccc}
\hline Parameters & QMI & QME & QS & PGR & LMP \\
\hline Tolerance & 0.76 & 0.46 & 0.22 & 0.71 & 0.19 \\
VIF & 1.30 & 2.14 & 4.53 & 1.39 & 5.03 \\
\hline
\end{tabular}

Table 6. Maize importation and other key determinants of local maize production (OLS and GLS)

\begin{tabular}{|c|c|c|}
\hline Variables & $\begin{array}{c}\text { OLSCoefficient } \\
\text { (Standard } \\
\text { error) }\end{array}$ & $\begin{array}{c}\text { GLS } \\
\begin{array}{c}\text { Coefficient (Standard } \\
\text { error) }\end{array} \\
\end{array}$ \\
\hline QMI & $\begin{array}{c}-0.0324 * * \\
(0.0159)\end{array}$ & $\begin{array}{c}-0.0324 * * \\
(0.0159)\end{array}$ \\
\hline QME & $\begin{array}{l}-0.0231 \\
(0.0212)\end{array}$ & $\begin{array}{l}-0.0231 \\
(0.0212)\end{array}$ \\
\hline QS & $\begin{array}{l}-0.967 * * * \\
(0.295)\end{array}$ & $\begin{array}{c}-0.967 * * * \\
(0.295)\end{array}$ \\
\hline PGR & $\begin{array}{c}-0.779 * * \\
(0.384)\end{array}$ & $\begin{array}{c}-0.779 * * \\
(0.384)\end{array}$ \\
\hline LMP & $\begin{array}{l}0.471 * * * \\
(0.0434)\end{array}$ & $\begin{array}{l}0.471 * * * \\
(0.0434)\end{array}$ \\
\hline Constant & $\begin{array}{c}28.42 * * * \\
(4.384)\end{array}$ & $\begin{array}{c}28.42 * * * \\
(4.384)\end{array}$ \\
\hline R-squared & 0.881 & \\
\hline $\mathrm{F}(5,41)$ & 60.45 & \\
\hline Prob $>F$ & 0.0000 & \\
\hline R-squared & 0.8805 & \\
\hline Adj R-squared & 0.8660 & \\
\hline $\begin{array}{l}\text { Breusch-Pagan / Cook-Weisberg test for } \\
\text { heteroskedasticity }\left(\text { Prob }>\mathrm{chi}^{2}\right)\end{array}$ & 0.0489 & \\
\hline Durbin-Watson d-statistics $(6,47)$ & 0.9644 & \\
\hline Normality (Jarque-Bera) test (Prob> chi ${ }^{2}$ ) & 0.000 & \\
\hline AIC & & 0.9364 \\
\hline BIC & & -152.418 \\
\hline
\end{tabular}




\section{CONCLUSION AND RECOMMENDATIONS}

The study was carried out to find out empirical evidence of the impact and the linearity between maize importation and other parameters on local maize production. The results of the unit root test and co-integration showed that all variables were stationary and co-integrated on the long run. Also, all the assumptions of OLS were fulfilled except for heteroscedasticity. The result of correlation coefficients showed that there is strong linear relationship among the major parameters and some were positively correlated while some are negatively correlated. Besides, the result of GLS showed that four important variables (quantity of maize imported, quantity of sorghum as substitute, population growth rate and local price of maize) are statistically significant and they strongly influenced local maize production.

Hence, the study recommended in line with the ISI strategy that strong and effective policy is needed to prevent or reduce maize importation, in order to encourage local maize production by the government. Price is also an important factor that encourages local production. Therefore, government should invest in technologies that will reduce local cost of production, so as to make locally produced maize more competitive in the global market in terms of price. There is already enough market for maize in Nigeria both for industrial use and final consumption. What is remaining is to implement and enforce policies and programmes that will enhance production so as to satisfy the market demand In addition, provide good markets for maize producers.

\section{REFERENCES}

ACOSTA, A. (2012). Measuring Spacial Transmission of White Maize Prices between South Africa and Mozambique: An Asymetric Error Correlation Model Approach. African Journal of Agriculture and Resource Economics, 7(1): 1-13, ISSN 19930-3738.

ADEWALE, A.R. (2017). Import substitution industrialisation and economic growth Evidence from the group of BRICS countries. Future Business Journal, 3(2): 138-158, https://doi.org/10.1016/j.fbj.2017.06.001

ADEWALE, A. R (2012). Does Import Substitution Industrialisation Strategy Hurt Growth? New Evidence from Brazil and South Africa. African and Asian Studies, 11 (6): 288314, DOI: $10.1163 / 15692108-12341235$; ISSN: 1569-2094

AKANDE, T. (2001). An overview of the Nigeria rice economy. Monograph of the Nigerian Institute of Social and Economic Research (NISER), Ibadan, Nigeria.

AKANNI, K. A \& OKEOWO, T. A. (2011). Analysis of aggregate output supply response of selected food grains in Nigeria, Journal of Stored Products and Postharvest Research 2(14): 266 - 278, ISSI 2141-6567

ALABI, O.F. \& ALABI, R.A. (2009).“Effect of economic and liberalization on chicken meat production in Nigeria", European Journal of Social Sciences. 7,4.

AYENI, A.O. (2011). 'Maize production in Nigeria: problems and prospects". Journal of food and agriculture, 2, 123-129

AYINDE, O. E., ILORI, T. E., AYINDE, K. \& BABATUNDE, R. O. (2015). "Analysis of the Behaviour of Prices of Major Staple Foods in West Africa: A Case Study of Nigeria", AGRIS on-line Papers in Economics and Informatics, 7(4): 3 - 17. ISSN 1804-1930. 
BAER, WERNER (1972). "Import Substitution and Industrialization in Latin America: Experiences and Interpretations", Latin American Research Review 7,1 (Spring): 95122, https://www.jstor.org/stable/2502457

CAMERON, A.C \& TRIVEDI, P.K. (2005). Microeconometrics, Methods and Applications, Published in the United States of America by Cambridge University Press, New York., pp345.

CHANG, HA-JOON (2002). Kicking Away the Ladder: Development Strategy in Historical Perspective. London: Anthem Press. CIA world fact book (2012).http://www.cia.gov/library/publications/theworldfactobook/geos/ni.html. (Accessed 27th March, 2018).

COLISTETE, R. P. (2010). Revisiting Import-Substituting Industrialisation in Post-War Brazil. Munich Personal ReP Ec Archiv, 5-8, Paper No. 24665

DEV, A. E. (2003). Import Substitution Industrialization: Looking Inward for theSource of Economic Growth, Puzzle of Latin America 3: 51-59

FAKOREDE, M.A. (2001). Revolutionizing Nigerian Agriculture With The Golden Seed Obafemi Awolowo University, Ile-Ife.

Food and Agriculture Organization of the United Nations. (1974). Report of the World Food Conference, Rome. Development Bibliography 8, Brighton: Institute of Development.

FAO global report on food crises, (2017). www.fao.org.

GARNETT, T. \& GODFRAY, C. (2012). Sustainable intensification in agriculture. Navigating a course through competing food system priorities. Food Climate Research Network and the Oxford Martin Programme on the Future of Food, University of Oxford, UK.

GOLDAR, B. (1986). Import substitution, industrial concentration and productivity growth in indian manufacturing. Oxford bulletin of economics and statistics, 48 (2): 143-164.

GUIMARÃES, A.Q. (2004). State Capacity and Economic Development: The advances and limits of import substitution industrialisation in Brazil.

HUNT, M. (2014). The World Transformed. New York: Oxford University Press. pp. 227228. ISBN 978-0-19-937102-0.

International Institute of Tropical Agriculture (IITA, 2017). "Sustainable food production in sub-Saharan African”.IITA's contribution. IITA, Ibadan.

IRWIN, A. D. 2002. Did Import Substitution Promote Growth in the Late Nineteen Century? National Bureau of Economic Research, Cambridge, NBER Working Paper 8751.

ISMAILA, U, GANA, A.S, TWANYA, N.M, \& DOGARA, D. (2010). Cereal production in Nigeria problems, constraints and opportunities for betterment. African Journal of Agricultural Research, 5(12): 1341-1350, ISSN 1991-637, DOI: 10.5897/AJAR09.407

KUAN, C.-M. (2004). Statistics: Concepts and Methods, 2nd edition Taipei: Hua-Tai, 495 pages. 
MADIBELA O. R. \& LEKGARI, L. A. (2002). Enhancing the commercial value of sorghum in Botswana. Botswana Notes and Records, 34, 107 - 112, nhttps://www.jstor.org/stable/40980326

MENDES, A. P. F., BERTELLA, M. A. \& TEIXEIRA, R.F.A. (2014). Industrialization in Sub-Saharan Africa and import substitution policy. Brazilian Journal of Political Economy, 34(1): 120-138,

National Bureau of Statistics (NBS) Quarterly report, (2017). National bureau of statistics foreign trade report.

National Population Commission Nigeria (NPC), (2010). Nigerian Demographic Survey, Federal Republic of Nigeria, Abuja.

NIENKE, M., BEINTDMa, \& GERT-JAN STADS. (2011). African agricultural R\&D in the new millennium, International Food Policy Research Institute, Food Policy Report.

NKWOCHA, A. 2012. Import Substitution: The new paradigm shift, Vanguard

OLANIYI, O.A. \& ADEWALE, J.G. (2012). "Information on Maize Production among Rural Youth: A Solution for Sustainable Food Security In Nigeria" (2012). Library $\begin{array}{llll}\text { Philosophy and } & \text { Practice }\end{array}$ http://digitalcommons.unl.edu/libphilprac/724

ONUK E. G., OGARA I. M , YAHAYA H \& NANNIM N (2010). Economic analysis of maize production in Mangu local government area of Plateau state, Nigeria. Journal of Production, Agriculture and Technology 6(1): 1-11, ISSN: 0794-5213

PANAGARIYA, A. (2002). A Case for Import Substitution? Publisher: Oxford University Press, pp 544.

POUGET-ABADIE, T. (2016). How successful was the policy of import substituting industrialisation in Latin America? London School of Economics and Political Sciences.

SHUMAN, M. H. (2006). The small-mart revolution: how local businesses are beating the global competition. San Francisco, CA: Berrett-Koehler, ISBN-13: 978-1576753866

UMA, K. E. (2007). "Population, agriculture, food and poverty in Nigeria: An over view," Journal of Management Sciences, 3, 23-43

OLADIMEJI, Y. (2017). trend of rice production and importation parameters in Nigeria from 1960-2015. Nigerian Journal of Agriculture, Food and Environment. 13(1): 126-132

ZHU, T. (2006). Rethinking ISI: Development Strategies and Institutions in Taiwan and China, ISSN 1810-2611 ISBN 92-9190-854-1 